\title{
Intra-annual variability of distribution patterns and fluxes of dissolved trace metals in a subtropical estuary (Danshuei River, Taiwan)
}

\author{
Kuo-Tung Jiann ${ }^{\mathrm{a}, *}$, Liang-Saw Wen ${ }^{\mathrm{b}}$ \\ a Institute of Marine Geology and Chemistry, National Sun Yat-Sen University, 804 Kaohsiung, Taiwan \\ b Institute of Oceanography, National Taiwan University, 106 Taipei, Taiwan
}

\section{A R T I C L E I N F O}

\section{Article history:}

Received 8 April 2008

Received in revised form 16 July 2008

Accepted 1 August 2008

Available online 9 August 2008

\section{Keywords:}

Trace metals

Estuarine chemistry

Removal

Variability

Danshuei River

Taiwan

\begin{abstract}
A B S T R A C T
Water samples were collected along salinity gradients and dissolved trace metal $(\mathrm{Cd}, \mathrm{Cu}, \mathrm{Ni}, \mathrm{Pb}$, and $\mathrm{Zn}$ ) concentrations were determined in a macro-tidal, mountainous estuary (Danshuei River Estuary) in northern Taiwan. Bi-monthly surveys were conducted between March 2001 and June 2002, during both wet and dry seasons. This study investigated intra-annual variability, fluxes, and the extent of addition or removal of dissolved trace metals in the estuary, which is characterized by the fluctuation of redox interface according to river flow conditions. In sub-oxic and anoxic waters, the presence of reduced sulfur species led to the formation of metal-sulfide minerals that sequester metals out of the water column. Therefore, trace metal fluxes and removal/addition rates are seasonally variable, largely by the extent of estuarine hypoxia. In the 9 sampling expeditions over the 16-month period, fluxes of dissolved trace metals out of the Danshuei River Estuary were estimated as follows: $\mathrm{Cd},-0.33-4.46 \mathrm{~mol} / \mathrm{day} ; \mathrm{Cu}$, -48-1112 mol/day; Ni, 1836-6586 mol/day; Pb, 2.47-11.59 mol/day; and Zn, 361-2656 mol/day. For elements such as $\mathrm{Cd}$ and $\mathrm{Cu}$, the removal in the Danshuei River Estuary during dry seasons was so dramatic that there were net fluxes from the coast to the estuary (negative fluxes). Ni behaved near conservatively in this estuary, thus its river endmember concentrations directly determined Ni fluxes out of the estuary. Removal of $\mathrm{Pb}$ was effectively enhanced by the presence of higher suspended particulate matter concentrations in the upper estuary and the formation of Fe- and Mn-oxides and oxyhydroxides that precipitate out of the water column in mid-estuary, which generally leaves low effective river endmember $\mathrm{Pb}$ concentrations, thus low fluxes out of the estuary.
\end{abstract}

(c) 2008 Elsevier B.V. All rights reserved.

\section{Introduction}

Trace metal behavior in estuarine waters is important for the assessment of their fluxes into coastal seas because chemical material may undergo transformation of pre-existing phases/ forms in the estuaries when passing through gradients of several important environmental parameters such as $\mathrm{pH}$, ionic strength and redox potential (Honeyman and Santschi, 1988; Zwolsman et al., 1997). Several important geochemical processes, such as precipitation/dissolution, adsorption/desorption, complexation, flocculation, and sedimentation involving trace metals occur at various extent when water chemistry changes

\footnotetext{
* Corresponding author. Tel.: +886 7 5252000x5160; fax: +886 75255130. E-mail address: ktjiann@fac.nsysu.edu.tw (K.-T. Jiann).
}

from riverine to seawater. These transformation processes affect distribution patterns and trace metal removal or addition in estuaries, and ultimately determine their fluxes into the ocean (Honeyman and Santschi, 1988; Santschi, 1988; Santschi et al., 1997; Wen et al., 1999).

In addition to the need for obtaining accurate trace metal fluxes in order to better estimate global river inputs into the ocean and to calculate oceanic residence times for trace elements, trace metal loadings in estuaries and coastal areas are a concern for pollution of river/estuarine systems in areas of high population and intensive industrialization. With high loadings of ammonium and organic matter from wastewater discharge that consume oxygen during oxidation and degradation processes, some parts of river/estuarine water may become oxygen depleted. Many such systems around the world are 


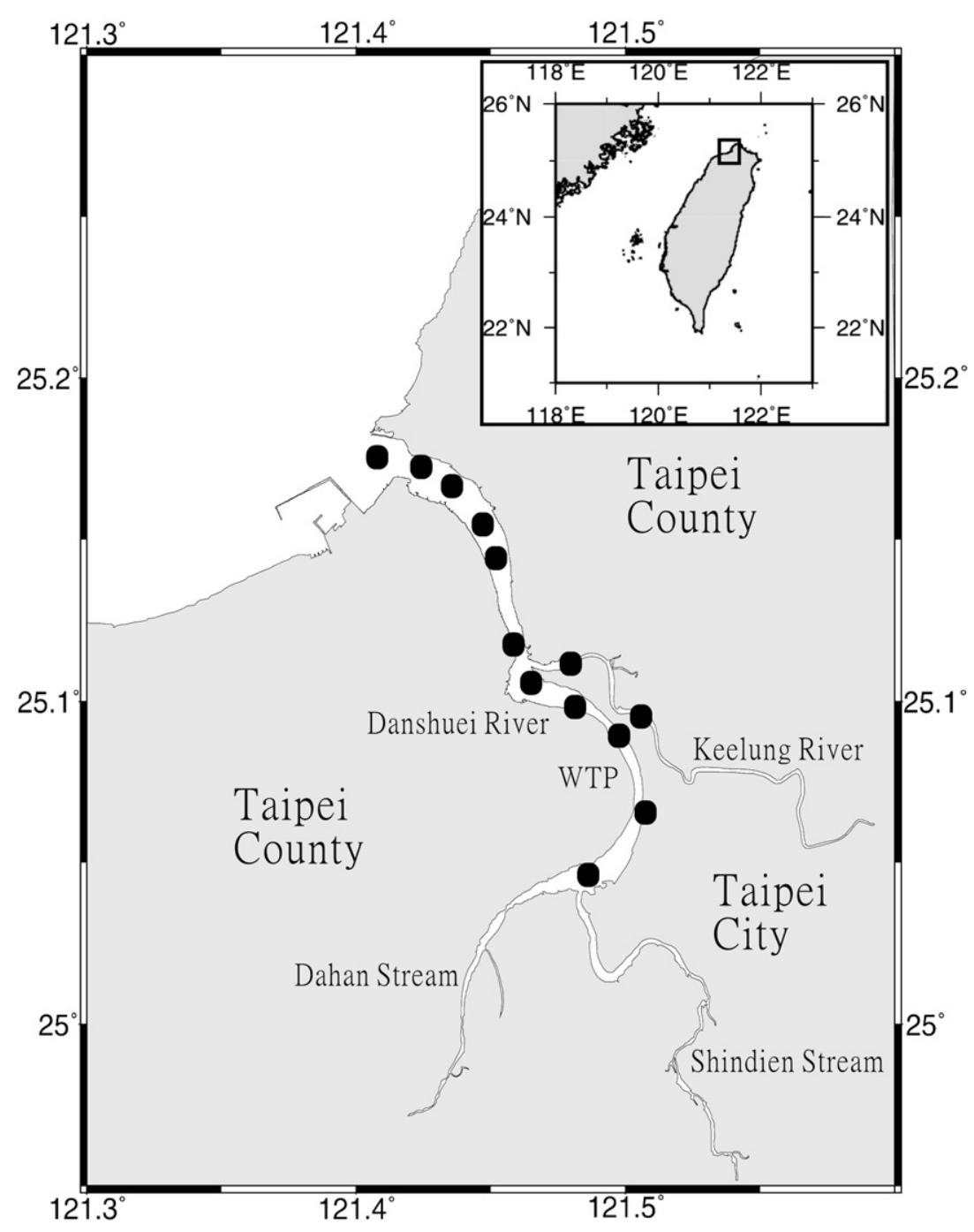

Fig. 1. The Danshuei River Estuary system. Sampling locations are marked with black dots and the wastewater treatment plant marked as WTP.

confronted with hypoxic condition. Trace metals such as $\mathrm{Cd}, \mathrm{Cu}$, $\mathrm{Pb}$, and $\mathrm{Zn}$ are active at redox interface (Ozturk, 1995; Pohl and Hennings, 1999). Therefore, trace metal fluxes out of anoxic estuaries are subject to the variability of hydrodynamic and redox condition in each system.

The Danshuei River and its tributaries (the Dahan and Hsindien Streams, and the Keelung River, Fig. 1) flow through the Taipei metropolitan area in northern Taiwan, including the City of Taipei and the Taipei County with a combined population of 6 million. Lower reaches of the watershed are subject to influence of domestic and industrial discharges, resulting in elevated nutrient and trace metal concentrations in the estuarine water (Jiann et al., 2005; Wen et al., 2008). Although Taiwan is a mountainous island, Taipei is located in Taipei Basin. Therefore, water flowing in this region is slowed down. The Danshuei River Estuary is a macro-tidal estuary, and the extent of saltwater intrusion is strongly affected by tides (Wang et al., 2004). Consequently, sections of the Danshuei River and its tributaries can become partly and temporally sub-oxic or anoxic, depending on river discharge and the degree of saltwater penetration.

Estimation of terrestrial material, including trace metals, transported to the ocean through estuaries requires accurate measurement of chemical fluxes. It has been widely accepted that trace metal concentrations measured in natural waters prior to the 1990s may need to be re-evaluated (Windom et al., 1991), after clean sampling techniques were developed specifically for trace metal analysis (e.g., the US EPA Method 1669). An earlier report in the Danshuei River Estuary (Jiann et al., 2005) suggested potential processes and mechanisms that affect trace metal distribution and partitioning. It is therefore important to determine the consequent flux estimation for trace metals through the estuary. With the accumulation of more accurate trace metal data obtained from estuaries worldwide, better estimates on trace metal fluxes into the ocean are obtained that will further provide information for the calculation of oceanic residence time of trace elements. 


\section{Materials and methods}

\subsection{Study area}

The Danshuei River, with its tributaries, is the largest river system in Taiwan, its watershed encompassing $2726 \mathrm{~km}^{2}$ and a combined length of $158.7 \mathrm{~km}$. Annual precipitation in the region ranges between $1500 \mathrm{~mm}$ and $2500 \mathrm{~mm}$, with the majority coming in late spring (May) to early fall (October). Long-term average annual river flow rate is $6600 \times 10^{6} \mathrm{~m}^{3} / \mathrm{y}$. Fig. 1 shows the Danshuei River/Estuary watershed with the re-occupied water sampling locations indicated. Contributions of freshwater from the three major tributaries are, on average, $27 \%$ from the Keelung River, 31\% from the Dahan Stream, and 37\% from the Shindien Stream. In the watershed of the Danshuei River system, most of the human population are concentrated in its lower reaches. Some of Taipei City's domestic wastewater, after primary treatment, is drained into the Danshuei River at $\sim 20 \mathrm{~km}$ from the river mouth (WTP, Fig. 1). The estuary receives industrial wastewater as well, mostly discharged in the upper estuary and riverine sections. The principal tidal constituents of the estuary leans toward semi-diurnal tides, with a mean tidal range of $2.1 \mathrm{~m}$ and a spring tidal range of $3.5 \mathrm{~m}$. Saltwater intrusion reaches in general $20-25 \mathrm{~km}$ from the river mouth, but can be as far as 40-50 km upstream. In the tidally affected sections, which include the entire sampling locations shown in Fig. 1, the water depth ranges from less than $1 \mathrm{~m}$ (upper Danshuei River) to $15 \mathrm{~m}$ (near where the Keelung River merges with the Danshuei River). Sand bars and barriers near the river mouth may have a limiting effect on seawater intrusion. The average flushing time of Danshuei River is 2-4 days (Wang et al., 2004).

\subsection{Water sampling}

The sampling effort applied in this study was a part of an integrated program in which hydrology, nutrients, and dissolved oxygen (DO), along with trace metals, were measured in surface water in the tidally affected Danshuei and Keelung Rivers (Fig. 1). The aim of this integrated program was to investigate and quantify environmental stressors in the estuarine and coastal regions of the Danshuei River watershed. Field sampling expeditions were carried out from March 2001 to June 2002. Two boats ( $3 \mathrm{~m}$ ) were used for surface water sampling and in situ hydrological data collection. Samples were collected during both tidal periods in order to cover the entire salinity range. Vertical profiles of temperature, salinity, dissolved oxygen (DO), fluorescence, $\mathrm{pH}$, and turbidity were recorded at each sampling location by a multi-sensor CTD unit (Hydrolab DataSonde 911). In general, the sampling stations were evenly spread and extended upstream approximately $25 \mathrm{~km}$ from the river mouth, and kept in the center of the river channel. Results of hydrology and basic water parameters are reported elsewhere (Wen et al., 2008). This study focuses on the trace metal findings of the above mentioned program.

Clean sampling techniques (Wen et al., 1996, 1999; Jiann and Presley, 2002) were closely followed during all phases of sample collection, treatments, and trace metal determination, which have been described earlier (Jiann et al., 2005). In summary, surface water samples were collected, starting at slack tides from the river mouth and moving upstream, and filtered in situ using an in-line filtration technique. The sampling assemblage included a 2-m polyethylene (PE) rod, on which a 3-m Teflon tubing was attached, a 1-m C-Flex tubing connecting the outlet of the Teflon tubing and a $0.45 \mu \mathrm{m}$ pore-sized capsule filter (Osmonics, Westborough, MA, USA). The C-Flex tubing was attached to a peristaltic pump and the Teflon tubing inlet was lowered to a depth of $\sim 25 \mathrm{~cm}$ into the river. At each sampling location, at least $10 \mathrm{~L}$ of water was pumped through the sampling assemblage prior to sample collection. Samples for the determination of total dissolved trace metal concentrations were filtered through the capsule filters, and dispensed directly into acid-washed bottles. Samples were preserved on ice and returned to the laboratory within a few hours.

\subsection{Trace metal analysis}

Upon returning to the laboratory, filtered samples were acidified to a $\mathrm{pH}<2$ by the addition of $2 \mathrm{~mL}$ of sub-boiled $\mathrm{HNO}_{3}$ (Seastar, Baseline grade). They were then UV-irradiated (8 lamps of $15 \mathrm{~W}$ each) for $12 \mathrm{~h}$ in order to mobilize trace metals in complexed, adsorbed, or mineral forms (Wen et al., 1996; Achterberg et al., 2001). Dissolved trace metal concentrations were determined after they were preconcentrated on Chelex-100 ion exchange resin (100-200 mesh, $\mathrm{NH}_{4}^{+}$ form, Bio-Rad), eluted with $7 \mathrm{~mL}$ of $2 \mathrm{~N} \mathrm{HNO}_{3}$ (Seastar, Baseling grade), and analyzed using a graphite furnace atomic absorption spectrometer (Varian SpectrAA 880Z). Accuracy of the entire analysis was assured by processing standard reference materials (SLRS-4, SLEW-3, both from the National Science Council of Canada) along with samples. Detection limits were $5 \mathrm{pM}$ for $\mathrm{Cd}, 0.3 \mathrm{nM}$ for $\mathrm{Cu}$ and $\mathrm{Ni}, 0.05 \mathrm{nM}$ for $\mathrm{Pb}$, and $0.5 \mathrm{nM}$ for $\mathrm{Zn}$. Recoveries of standard reference materials were between 92 and $110 \%$. Results of duplicate field samples showed that relative percentage differences were $5-10 \%$.

\subsection{Calculation of trace metal fluxes}

In a conventional manner, distribution patterns of aquatic constituents in estuaries are normally presented in chemicalsalinity plots (Officer, 1979). A linear relationship in those plots indicates that the specific constituent behaves conservatively in the estuary. A concave or convex curve implies removal or addition of the constituent in estuaries, respectively. For many trace elements, significant extent of removal or addition occurs in the upper estuary, or in low salinity regions, while a more linear relationship is observed near the river mouth, or high salinity sections of the estuaries. When non-conservative mixing behavior is observed for a specific element, the extrapolation of data points of higher salinity sections on the metal-salinity plot to zero salinity yields an effective river endmember concentration, $C^{*}$, which is different from the observed river endmember concentration, $C^{0}$. The fluxes, or export loadings, to the ocean are estimated by multiplying effective river concentration $\left(C^{*}\right)$ by river discharge $(Q)$, and the net internal input or removal is given by the difference, $F_{\text {int }}=Q\left(C^{*}-C^{0}\right)$. This standard box model is useful in elucidating estuarine processes.

Since one of the tributaries of the Danshuei River (the Keelung River) merges into the mainstream relatively close to 
the river mouth $(\sim 15 \mathrm{~km})$ at mid-salinity range (10-20), calculating fluxes of trace metals from the Danshuei River Estuary to the coast should only consider those data in the lower estuary after the convergence of all tributaries. Since most processes (input and removal) involving trace metals occur in the upper estuary and since subsequent mixing is more predominant in the lower estuary (Zwolsman et al., 1997; Chiffoleau et al., 1999), this study only used results for waters collected in the lower estuary with salinity $>15$ and below the convergence point of the Danshuei and Keelung Rivers to derive effective river concentrations. The section of the Keelung River where sampling was conducted was always affected by mixing with the Danshuei River water between tidal cycles; hence only the observed river endmember concentrations from the Danshuei River, the mainstream of the system, were used for internal removal/addition calculation. Coastal endmember concentrations $C^{C}$, were taken as observed values, or extrapolated to salinity 33.5 (average Danshuei coastal salinity) from linear regression of the metalsalinity relationship in the lower estuary, the same regression for deriving $C^{*}$. Trace metal concentrations of the Keelung River samples were plotted on the metal-salinity plots using different symbols for reference. Internal removal or addition (percentage relative to river endmember concentration) was calculated as $R_{\mathrm{int}}=\left(C^{0}-C^{*}\right) / C^{0}$, with positive values indicating removal and negative values implying the extent of addition within the estuary. Trace metal fluxes were calculated by multiplying observed discharge by effective river endmember concentration for each sampling survey.

\section{Results and discussion}

\subsection{Hydrology}

During the study period, seasonal climate patterns, in general, followed long-term patterns, with the majority of annual precipitation and higher river discharge occurring between March and October 2001 (Fig. 2). However, in September 2001, Typhoon Nari brought extremely large amounts of precipitation to the region $(1500 \mathrm{~mm}$ in September 2001), but very little rain afterwards until June 2002 (Jiann et al., 2005). As a result, dissolved oxygen (DO) in October 2001 was generally high in the entire estuary (>100 $\mu \mathrm{M}$, except for the Keelung River), and extremely low in the upper estuary in most of the other sampling times (Wen et al., 2008), as shown in Fig. 3. The low DO concentrations were a result of high oxygen consumption due to wastewater discharge into the river, as evidenced by the very high ammonium concentrations (up to $800 \mu \mathrm{M}$ ) in the January 2002 river waters (Jiann et al., 2005; Wen et al., 2008). River discharge data are obtained from an upstream location with available daily gauge data (Water Resource Agency, 2003) and calibrated with our field measurement near the river mouth. The relatively high river discharge in October $2001\left(183 \mathrm{~m}^{3} / \mathrm{s}\right.$, much higher in days prior to sampling, Fig. 2) had a substantial dilution effect on concentrations of chemical constituents in estuarine water, along with possibly higher urban runoffs.

With the episodic events such as typhoons and torrential rains interrupting the watershed's normal flow condition, at the same time they effectively introduce large fluxes of oxygenated water into the estuary. The oscillation of DO
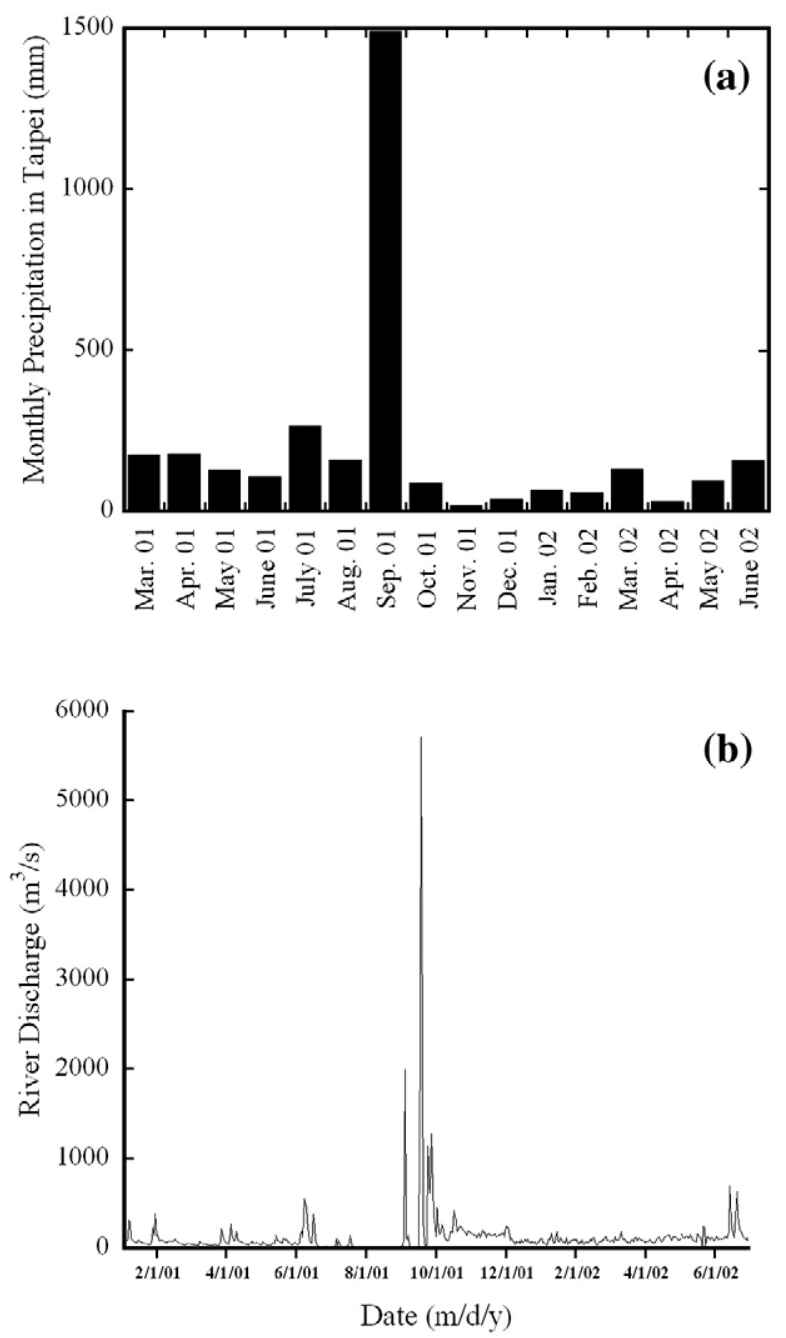

Fig. 2. Precipitation in the Taipei region (a) and river discharge of the Danshuei River (b).

concentrations and ultimately redox conditions within the estuary are results of the combined effects from river discharge, wastewater discharge, and flushing time in the estuary. This fluctuating redox state in the estuary is the most intriguing feature that plays a major role in controlling trace metal behavior. It was found that except for the October 2001 sampling survey, at least part of the Danshuei River Estuary was under hypoxic condition $(\mathrm{DO}<60 \mu \mathrm{M})$ during each expedition (Fig. 3). In all sampling trips conducted in 2002, surface waters in the upper estuary had DO concentrations at, or near, $0 \mu \mathrm{M}$. Up to $500 \mu \mathrm{M}$ of total dissolved sulfide was observed in the near-zero DO waters of the Danshuei River Estuary during the January, 2002 survey (Jiann et al., 2005), and in situ measurement of surface water redox potential has shown that in the low DO waters, redox state was sub-oxic to near anoxic $(<-100 \mathrm{mV}, \mathrm{Fig}$. 3$)$. It can be expected that bottom water and sediment would be more reducing. With the presence of total dissolved sulfide at high concentrations, it is not surprising to observe other redox reactions occurring in the estuary, i.e., those involving $\mathrm{Fe}, \mathrm{Mn}$ and other metals. As 

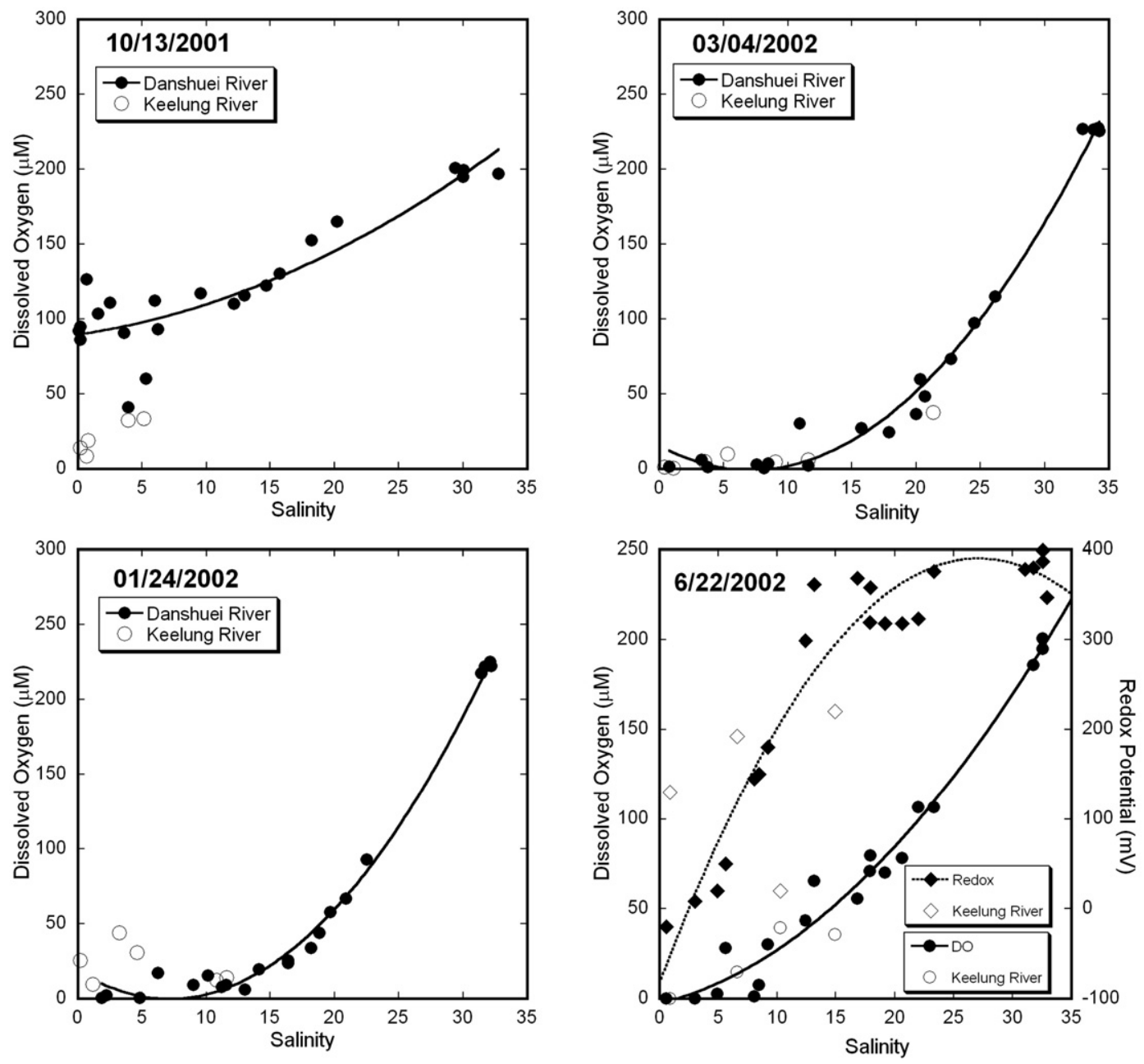

Fig. 3. Distribution of dissolved oxygen (DO) and redox potential (only in June 2002) along salinity gradients in the Danshuei River Estuary.

pointed out in Jiann et al. (2005), during low river flow seasons, the formation of reduced sulfur species greatly contributes to removal of several trace elements in the upper Danshuei River Estuary. Thus the fluctuation of DO concentrations and consequent redox conditions in the estuarine waters would strongly affect removal process of trace metals (Paucot and Wollast, 1997; Jiann et al., 2005), and their fluxes out of the estuary.

\subsection{Endmember concentrations}

In the Danshuei River Estuary, with a relatively short average flushing time of 2-4 days, any episodic weather event can have significant effects on hydrochemical condition and trace metal concentrations in the estuarine water. High river discharge would have a dilution effect, but at the same time increased urban runoffs could elevate inputs (Jiann et al., 2005). These effects are element-specific and vary under different estuarine hydrological conditions. However, since trace metal samplings were 1-3 months apart, the periodicity of any short-term source variations that may be superimposed on the yearly cycle could not be resolved.
Without considering varying external metal sources, there are two major factors that affect variability of river endmember concentrations: 1 ) river discharge; and 2) redox state in the river section and upper estuary. With frequently observed sub-oxic and anoxic condition in the upper Danshuei River Estuary, river endmember concentrations in the Danshuei River Estuary could have been underestimated because part of the metals entering the low DO upper estuarine waters may have been removed as soon as these are discharged into the river.

Observed river endmember concentrations $\left(C^{0}\right)$ are listed in Table 1, and large variations were found: $\mathrm{Cd}, 36-270 \mathrm{pM}$; $\mathrm{Cu}, 75-225 \mathrm{nM}$; Ni, 146-567 nM; Pb, 1.2-15.0 nM; and Zn, 50$120 \mathrm{nM}$. There were little co-occurrences of maximal and minimal endmember concentrations of the various trace elements determined, indicating these metals are discharged into the estuary at different loadings or sources. Since $\mathrm{Ni}$ is the least reactive metal among the elements determined in this study (Jiann et al., 2005), a relationship between river endmember concentration of $\mathrm{Ni}$ and river discharge (5-day running average) was established (Fig. 4) to elucidate the effect of river discharge on river endmember concentration. A 
Table 1

Observed river and coastal endmember concentration $C^{0}$ and $C^{C}$, effective river endmember concentration $C^{*}$, estuarine export loading (fluxes), $F_{\text {est }}{ }^{\text {a }}$, and percentage of addition/removal $R_{\text {int }}{ }^{\mathrm{b}}$ of trace metals in the Danshuei River Estuary for the 9 sampling expeditions conducted between March 2001 and June 2002

\begin{tabular}{|c|c|c|c|c|c|c|c|c|c|c|c|}
\hline \multicolumn{3}{|c|}{ Sampling date } & \multirow{2}{*}{$\frac{03 / 16 / 01}{110}$} & \multirow{2}{*}{$\frac{06 / 19 / 01}{105}$} & \multirow{2}{*}{$\frac{07 / 18 / 01}{123}$} & \multirow{2}{*}{$\frac{10 / 13 / 01}{183}$} & \multirow{2}{*}{$\frac{12 / 26 / 01}{69}$} & \multirow{2}{*}{$\frac{01 / 24 / 02}{52}$} & \multirow{2}{*}{$\frac{03 / 04 / 02}{82}$} & \multirow{2}{*}{$\frac{05 / 07 / 02}{137}$} & \multirow{2}{*}{$\frac{06 / 22 / 02}{214}$} \\
\hline Riv & ischat & $\left.\mathrm{m}^{3} / \mathrm{s}\right)$ & & & & & & & & & \\
\hline \multirow[t]{5}{*}{$\overline{\mathrm{Cd}}$} & $C^{*}$ & $\mathrm{pM}$ & -27 & 53 & 24 & 282 & 142 & -28 & -46 & 10 & 27 \\
\hline & $C^{0}$ & pM & 225 & 200 & 220 & 270 & 95 & 80 & 70 & 36 & 55 \\
\hline & $C^{C}$ & pM & 105 & 130 & 90 & 170 & 110 & 70 & 90 & 60 & 55 \\
\hline & $F_{\text {est }}$ & $\mathrm{mol} /$ day & -0.26 & 0.48 & 0.28 & 4.46 & 0.85 & -0.13 & -0.33 & 0.12 & 0.50 \\
\hline & $R_{\text {int }}$ & (\%) & 112 & 74 & 89 & -4 & -49 & 135 & 166 & 72 & 51 \\
\hline \multirow[t]{5}{*}{$\mathrm{Cu}$} & $C^{*}$ & $\mathrm{nM}$ & 38.7 & 35.8 & 19.8 & 70.3 & 28.2 & 21.5 & -6.8 & -1.8 & 3.8 \\
\hline & $C^{0}$ & $\mathrm{nM}$ & 200 & 200 & 100 & 150 & 225 & 150 & 115 & 100 & 75 \\
\hline & $C^{C}$ & $\mathrm{nM}$ & 10 & 17 & 9 & 9 & 6 & 4 & 14 & 16 & 20 \\
\hline & $F_{\text {est }}$ & mol/day & 368 & 325 & 226 & 1112 & 168 & 97 & -48 & -21 & 71 \\
\hline & $R_{\mathrm{int}}$ & (\%) & 81 & 82 & 80 & 53 & 87 & 86 & 106 & 102 & 95 \\
\hline \multirow[t]{5}{*}{$\mathrm{Ni}$} & $C^{*}$ & $\mathrm{nM}$ & 693 & 278 & 240 & 259 & 308 & 444 & 389 & 414 & 326 \\
\hline & $C^{0}$ & $\mathrm{nM}$ & 522 & 190 & 146 & 265 & 328 & 567 & 339 & 382 & 258 \\
\hline & $C^{C}$ & $\mathrm{nM}$ & 29 & 14 & 6 & 7 & 6 & 6 & 14 & 12 & 9 \\
\hline & $F_{\text {est }}$ & mol/day & 6586 & 2522 & 2737 & 4095 & 1836 & 1995 & 2756 & 4900 & 6028 \\
\hline & $R_{\mathrm{int}}$ & (\%) & -33 & -46 & -64 & 2 & 6 & 22 & -15 & -8 & -26 \\
\hline \multirow[t]{5}{*}{$\mathrm{Pb}$} & $C^{*}$ & $\mathrm{nM}$ & 1.22 & 0.45 & 0.34 & 0.36 & 0.54 & 0.71 & 0.35 & 0.57 & 0.31 \\
\hline & $C^{0}$ & $\mathrm{nM}$ & 5.00 & 11.50 & 15.00 & 1.80 & 1.20 & 2.07 & 2.20 & 1.36 & 2.20 \\
\hline & $C^{C}$ & $\mathrm{nM}$ & 0.20 & 0.40 & 0.09 & 0.18 & 0.10 & 0.11 & 0.09 & 0.15 & 0.05 \\
\hline & $F_{\text {est }}$ & $\mathrm{mol} /$ day & 11.59 & 4.06 & 3.92 & 5.68 & 3.20 & 3.18 & 2.47 & 6.79 & 5.81 \\
\hline & $R_{\text {int }}$ & (\%) & 76 & 96 & 98 & 80 & 55 & 66 & 84 & 58 & 86 \\
\hline \multirow[t]{5}{*}{$\mathrm{Zn}$} & $C^{*}$ & $\mathrm{nM}$ & & & & 168 & & 80 & & 72 & 76 \\
\hline & $C^{0}$ & $\mathrm{nM}$ & & & & 120 & & 120 & & 50 & 60 \\
\hline & $C^{C}$ & $\mathrm{nM}$ & & & & 7 & & 4 & & 7 & 10 \\
\hline & $F_{\text {est }}$ & mol/day & & & & 2656 & & 361 & & 848 & 1403 \\
\hline & $R_{\text {int }}$ & $(\%)$ & & & & -40 & & 33 & & -43 & -27 \\
\hline
\end{tabular}

${ }^{a} F_{\text {est }}$ : estuarine metal flux (negative values indicate net flux from coast to estuary.

b $R_{\text {int }}$ : percentage of metal removed in estuary, negative values indicate percentage of metal addition relative to observed river endmember concentration in estuary.

general inverse correlation was found, which clearly shows the dilution effect on river endmember concentrations.

Coastal endmember concentrations $\left(C^{C}\right)$, taken as observed if salinity $>33.5$, or extrapolated from the linear metal concentration vs. salinity relationship if river mouth station had water salinity $<33.5$, showed the extent of river plume extension and metal concentrations after estuarine processes. Large variations were found for coastal endmember concentrations of trace metals (Table 1): Cd, 55-170 pM; Cu, 420 nM; Ni, 6-29 nM; Pb, 0.05-0.4 nM; and Zn, 4-10 nM.

\subsection{Distribution patterns of trace metals}

In the previous report (Jiann et al., 2005) detailing variation of trace metal distribution and partitioning for $\mathrm{Cd}$, $\mathrm{Cu}, \mathrm{Ni}$, and $\mathrm{Pb}$, most of the variation in dissolved metal concentration observed was influenced by river discharge and the redox states of estuarine waters. Those findings were clearly revealed when distinct distribution patterns of chemical affinity fractions of trace metals under different river flow conditions showed contrasting patterns. Although this study does not include trace metal fraction data, the observed distribution patterns of dissolved trace metals provide valuable information that allows for elucidating temporal variation of trace metal fluxes. In Jiann et al. (2005), non-conservative, with "addition" estuarine mixing features for $\mathrm{Cd}, \mathrm{Cu}, \mathrm{Ni}$, and $\mathrm{Pb}$ were observed during high river flow condition (October 2001), which provided oxygenated water throughout the estuary. Concave curves in the metalsalinity plots, implying strong removal of metals, were seen for all metals analyzed during dry conditions (Jiann et al., 2005). The results strongly indicate that when parts of the estuary were under anoxic or sub-oxic condition, the presence of sulfide species would result in the formation of metal-sulfide minerals, which ultimately deposit into estuarine sediments. This process effectively removes trace metals such as $\mathrm{Cd}, \mathrm{Cu}, \mathrm{Pb}$, and to a less extent, $\mathrm{Ni}$ from the dissolved metal pools, as evidenced by the results of spatiotemporal variations in size fractions, chemical affinity fractions, and

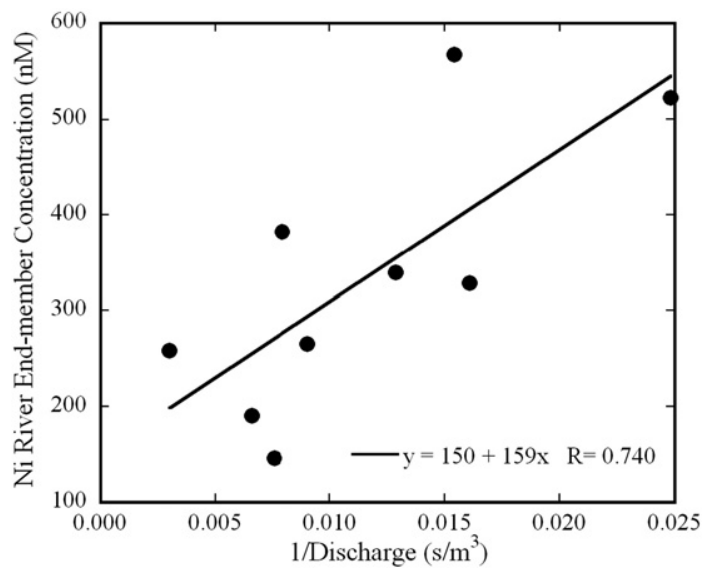

Fig. 4. Relationship between dissolved Ni river endmember concentration with the reciprocal of river discharge (5-day running average). A linear correlation implies the dilution effect on dissolved metal river endmember concentration from elevated river discharge. 

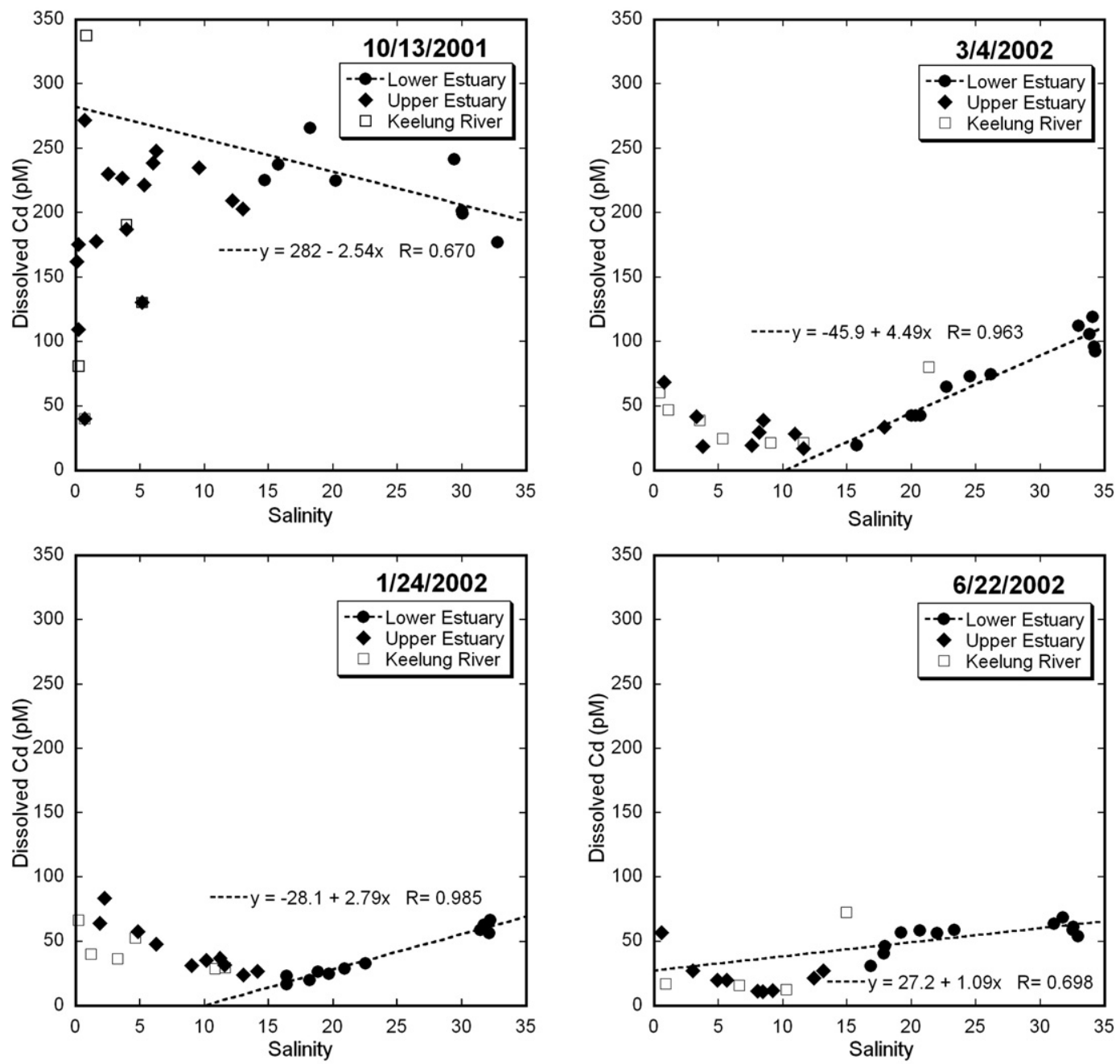

Fig. 5. Distribution of dissolved Cd along salinity gradients in the Danshuei River Estuary and modeled (implied mixing) regression of Cd and salinity in the lower estuary.

concentrations in suspended particles and sediments of those metals (Jiann et al., 2005).

Figs. 5-9 illustrate typical distribution patterns of the five trace metals determined in this study, which include all types of trace metal mixing behavior observed. Cd was observed to behave non-conservatively often; October (Fig. 5) and December of 2001 were the only times that $\mathrm{Cd}$ did not show removal behavior. During the times under removal of $\mathrm{Cd}$ in the Danshuei River Estuary was observed, the lowest Cd concentrations were found in the mid-salinity range (5-17) of the estuary instead of in the coastal waters. This interesting and frequent finding of the $\mathrm{V}$-shaped $\mathrm{Cd}$ distribution along the salinity gradient and an extremely strong removal of $\mathrm{Cd}$, essentially $100 \%$, was reported for the January 2002 survey and explained by results of dissolved metals fractions mentioned in the previous report (Jiann et al., 2005).

The dissolved $\mathrm{Cu}$ distribution showed concave removal behavior in the Danshuei River Estuary (Fig. 6) during all nine sampling surveys. The presence of V-shaped Cu-salinity plots, like those of Cd, was seen in March and June of 2002, as shown in Fig. 6 (also in May 2002 but not shown). By comparing dissolved $\mathrm{Cu}$ distribution patterns in the Danshuei River Estuary over time, it is clear that only when or shortly after the estuary was flushed with oxygenated water did the dissolved Cu-salinity plot appear closer to a linear relationship.

$\mathrm{Ni}$ is less reactive toward sulfide in comparison with $\mathrm{Cd}, \mathrm{Cu}$ and $\mathrm{Pb}$ (Jiann et al., 2005). Therefore, distribution patterns of dissolved $\mathrm{Ni}$ in the Danshuei River Estuary were close to conservative mixing behavior (Fig. 7). Water of the Keelung River, a tributary of the Danshuei River, merges into the main stream not far from the river mouth $(\sim 15 \mathrm{~km})$, contributes $27 \%$ of the river discharge and has much lower dissolved $\mathrm{Ni}$ concentration. Hence it has a dilution effect on the lowered $\mathrm{Ni}$ concentrations in the estuarine section just above the convergence point during flood tide. Salinity of the mixed water was generally at or near 15 . If the dilution effect from mixing with the Keelung River water was considered, distribution patterns of dissolved $\mathrm{Ni}$ in the Danshuei River Estuary would have been much more linear except for 2 sampling expeditions, July 18, 2001 and January 24, 2002, which displayed addition and removal behavior, respectively. 

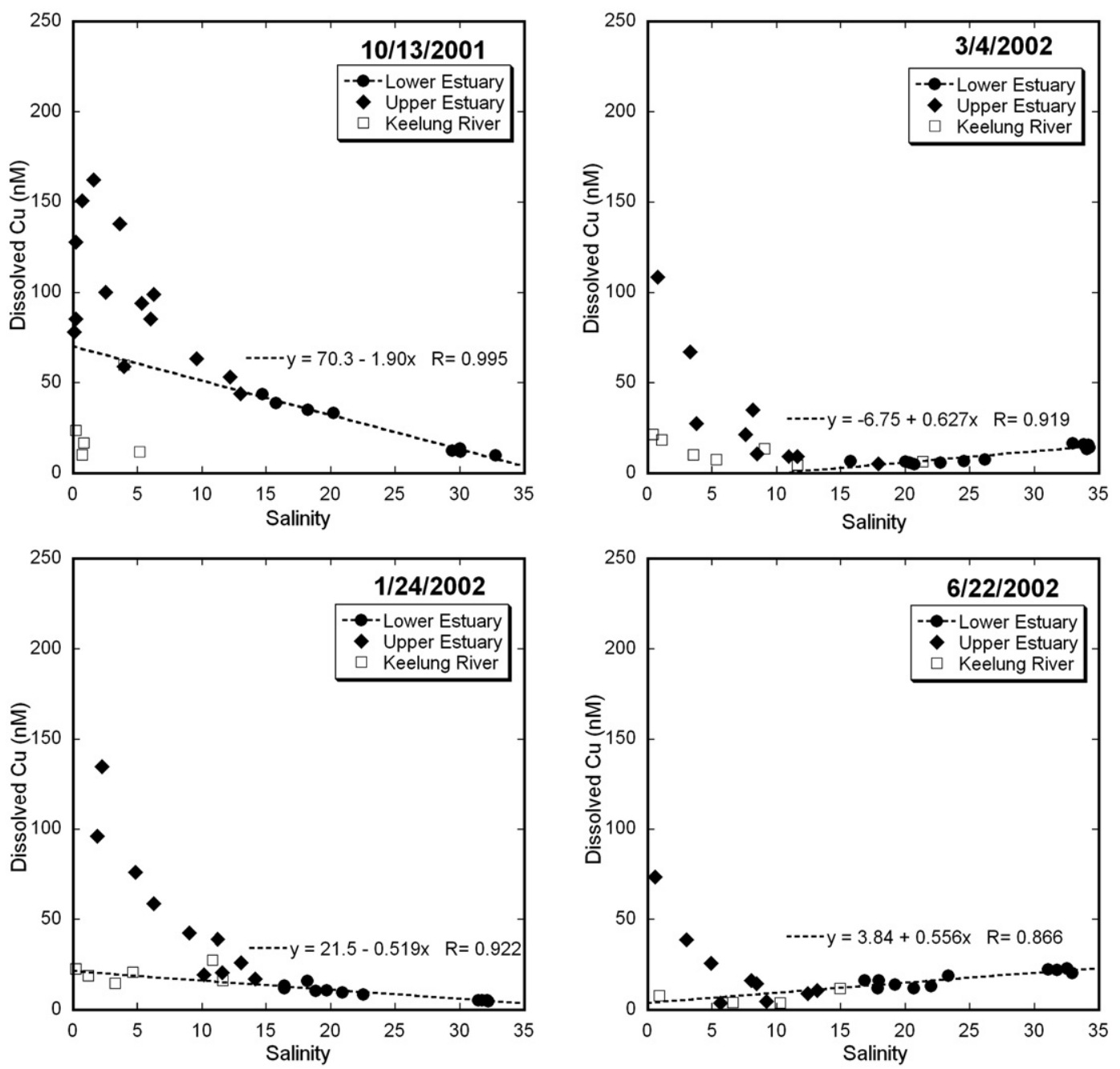

Fig. 6. Distribution of dissolved Cu along salinity gradients in the Danshuei River Estuary and modeled (implied mixing) regression of Cu and salinity in the lower estuary.

In contrast to that of $\mathrm{Ni}$, dissolved $\mathrm{Pb}$ in the Danshuei River Estuary showed the most consistent removal feature (Fig. 8). Dissolved $\mathrm{Pb}$ concentrations decreased rapidly, usually in relatively low salinity range, and continued to decrease gradually in mid-estuary. In the lower estuary, dissolved $\mathrm{Pb}$ concentrations varied very little and at times were even near constant. This strong concave distribution pattern of $\mathrm{Pb}$ for all sampling expeditions, regardless of the redox or flow conditions of the estuary, indicating removal of $\mathrm{Pb}$, is distinct when comparing them with those of other elements determined in this study. While $\mathrm{Cd}, \mathrm{Cu}$, and Ni showed different mixing behavior (linear, convex, concave, or V-shaped) under various river flow and redox conditions, the particle-reactive element $\mathrm{Pb}$ showed a distinct removal pattern in the Danshuei River Estuary.

Although there were only four surveys with $\mathrm{Zn}$ data, results show distinct distribution patterns of $\mathrm{Zn}$ in the Danshuei River Estuary under different flow conditions. After the flood in the watershed resulting in high river discharge in the river (October 13, 2001), $\mathrm{Zn}$ in the Danshuei River Estuary had internal inputs in the lower to mid-salinity region, and conservative mixing behavior was found in the lower estuary (Fig. 9). During low flow months (January, May, and June 2002), a strong removal feature was found in the upper estuary, while mixing was predominant in the lower estuary.

\subsection{Fluxes and removal (addition) extent of trace metals}

As mentioned earlier, river endmember concentrations may have been underestimated. The extent of removal estimated here represents a conservative or minimal value. But metal fluxes calculated are satisfactorily accurate, as most of the linear regressions between dissolved metal concentration and salinity are statistically significant. Fluxes (export loadings) of dissolved trace metals $\left(F_{\text {est }}\right)$ out of the estuary, and the relative amount of internal input or removal of dissolved trace metals $\left(R_{\text {int }}\right)$ within the estuary were estimated using observed river discharge (Water Resource Agency, 2003), observed and effective river endmember concentrations ( $C^{0}$ and $C^{*}$, respectively) for trace metals (Table 1). Positive values of fluxes $\left(F_{\text {est }}\right)$ indicate the rates of 

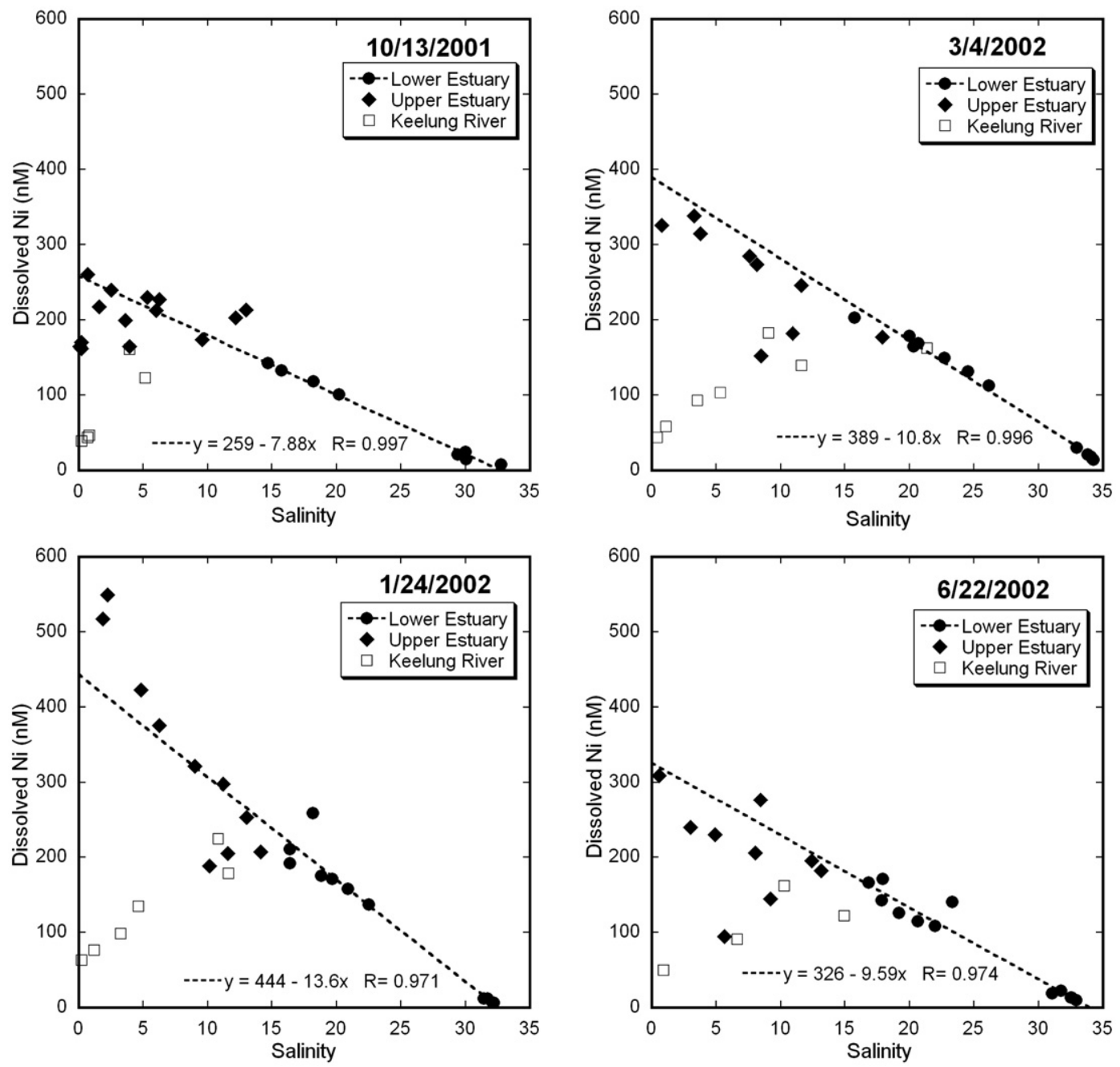

Fig. 7. Distribution of dissolved Ni along salinity gradients in the Danshuei River Estuary and modeled (implied mixing) regression of Ni and salinity in the lower estuary.

metals being exported out of the estuary. For internal input or removal $\left(R_{\mathrm{int}}\right)$, the values are the percentage of metals being added or removed within the estuary compared to that from the river, with negative values implying addition. In some occasions, $R_{\text {int }}$ values were greater than $100 \%$, corresponding with negative flux values $\left(F_{\text {est }}\right)$. This indicates that for some trace metals, coastal water provided additional metal inputs. Some extent of the metal of coastal source was removed in the estuary after entering the estuary. Among the elements determined in this study, $\mathrm{Cu}$ and $\mathrm{Pb}$ were always removed in the Danshuei River Estuary, as well as all but two sampling surveys for $\mathrm{Cd}$. On four occasions, there were moderate amounts of $\mathrm{Ni}$ addition observed or as calculated from $\mathrm{Ni}-$ salinity plots. However, these estimates of Ni addition may be overestimated due to the dilution effect from the low-Ni Keelung River water merging into the Danshuei River Estuary.

Trace metal fluxes out of the Danshuei River Estuary are compared with other systems of the same magnitude of discharge and have concerns of trace metal pollution (Table 2). Of the systems that are compared, the Clyde Estuary in Scotland (Muller et al., 1994) represents the only system with trace metal fluxes ( $\mathrm{Cu}$ and $\mathrm{Ni}$ ) smaller than those in the Danshuei River Estuary. It should be noted that the greatest oxygen depletion in the Danshuei River Estuary occurred in 2002 , when extremely low DO $(<15 \mu \mathrm{M})$ was observed in surface water of salinity $<10$ (Wen et al., 2008). It is estimated that during times of normal and low river flow, $>40 \%$ of the estuarine water was under hypoxic condition. This extent of hypoxia greatly affects trace metal removal and mobilization.

\subsubsection{Cadmium and copper}

Due to the frequently occurring sub-oxic to anoxic conditions in the upper Danshuei River Estuary, trace elements such as $\mathrm{Cd}$ and $\mathrm{Cu}$ are efficiently removed in the estuary, except for high river flow seasons during which the entire estuarine water was oxygenated (e.g., October 2001). This is clearly shown in the $\mathrm{Cd}-$ and $\mathrm{Cu}$-salinity plots (Figs. 5 and 6) and mathematically expressed in Table 1. Trace metal fluxes out of the Danshuei River Estuary $\left(F_{\text {est }}\right)$ for dissolved $\mathrm{Cd}$ and Cu were greatest on the October 13, 2001 sampling trip, 4 weeks after a flooding event resulted from Typhoon Nari. During the drought period following the 2001 flooding, dissolved Cd and Cu fluxes out of 

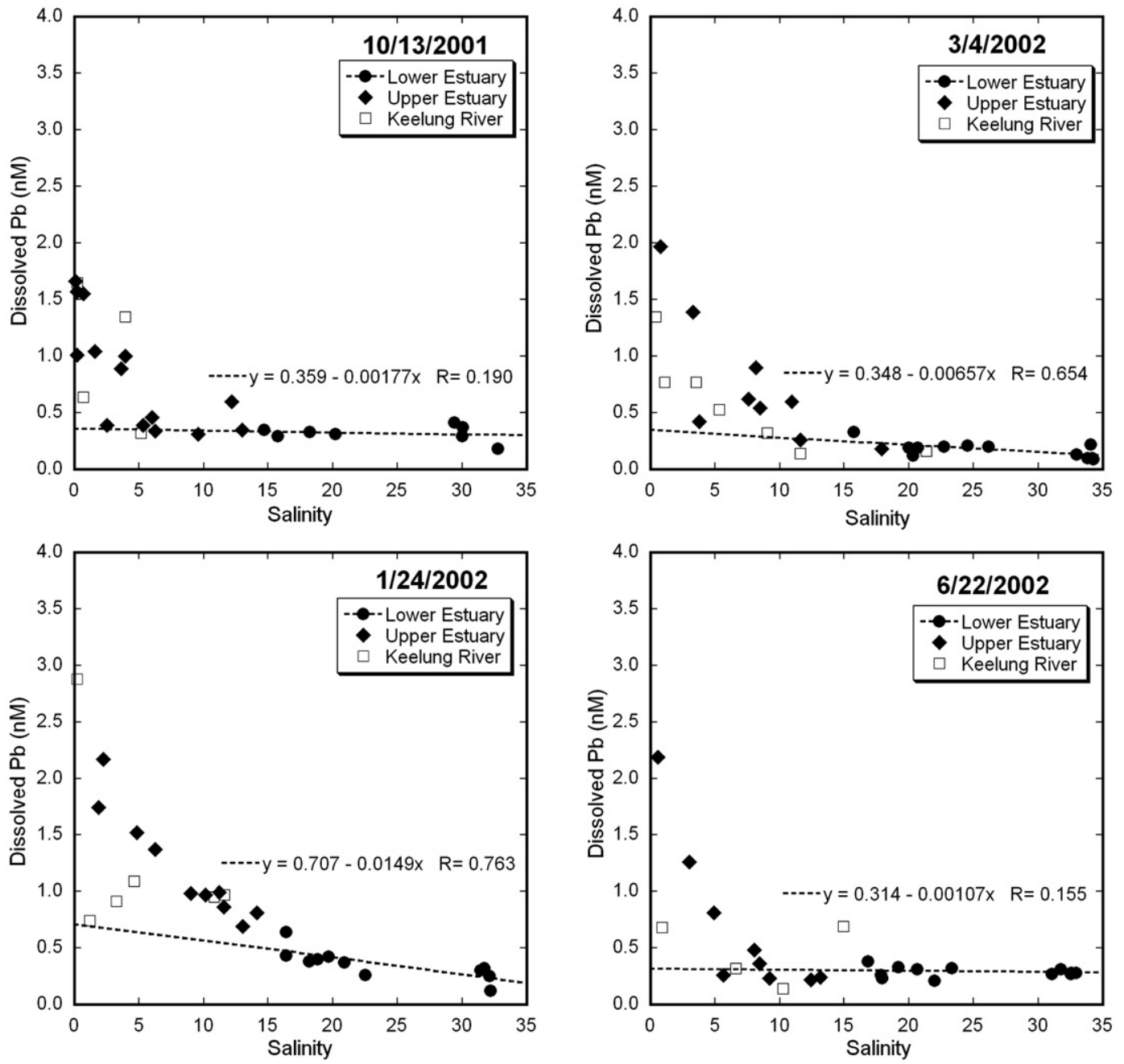

Fig. 8. Distribution of dissolved $\mathrm{Pb}$ along salinity gradients in the Danshuei River Estuary and modeled (implied mixing) regression of Pb and salinity in the lower estuary.

the estuary were much lower; at times there were even dissolved $\mathrm{Cd}$ and $\mathrm{Cu}$ fluxes from the coast into the estuary. Negative fluxes of trace metals occurred when V-shaped distribution patterns were observed, implying that due to a great extent of removal in mid-estuary, there was a positively correlated relationship between dissolved metal concentration and salinity. Dissolved Cd flux ranged between $-0.33 \mathrm{~mol} /$ day (coast to estuary) and $4.46 \mathrm{~mol} /$ day (estuary to coast). Only after the entire estuary was flushed with oxygenated water were there internal inputs of dissolved $\mathrm{Cd}$ in the Danshuei River Estuary (October and December 2001, Table 1). At times when at least part of the estuary was sub-oxic to anoxic, more than $50 \%$ and as much as $160 \%$ of dissolved Cd was removed in the estuary. For $\mathrm{Cu}$, its dissolved flux ranged from $-48 \mathrm{~mol} / \mathrm{day}$ to $1112 \mathrm{~mol} /$ day. The flux was highest after high river flow condition and progressively declined through the drought period (December 2001 to May 2002). This feature of high removal of $\mathrm{Cd}$ and $\mathrm{Cu}$ in low DO waters has been reported in other sub-oxic or anoxic estuaries, e.g., the Scheldt (Paucot and Wollast, 1997; Zwolsman et al., 1997), and Seine Estuaries (Chiffoleau et al., 1994). The Danshuei River Estuary has an average dissolved Cd flux of $0.66 \mathrm{~mol} / \mathrm{day}$, which is $2-3$ orders of magnitude smaller than those of the other systems compared, although river discharge in the Danshuei River Estuary is in the same order of magnitude with the Scheldt (Zwolsman et al., 1997) and Clyde Estuaries (Muller et al., 1994), and 4-10 times smaller than the Seine (Chiffoleau et al., 1994, 1999) and Gironde Estuaries (Michel et al., 2000). For Cu, its dissolved flux in the Danshuei River Estuary is similar to that of the smaller Clyde Estuary and lower by a factor of 2.5-30 compared with the Scheldt, Seine and Gironde (Table 2). However, actual, observed river endmember concentrations of dissolved $\mathrm{Cu}$ in the Danshuei River were much higher than those of the other estuaries listed in Table 2. This indicates that due to the elevated concentrations of reduced sulfur species found in the upper Danshuei River Estuary, removal of dissolved $\mathrm{Cu}$ was more efficient (high removal rates) in the Danshuei system than the others.

The high removal rates and smaller fluxes of dissolved Cd and $\mathrm{Cu}$ in the partly anoxic Danshuei River Estuary are evidenced by their negative fluxes observed toward the end of the drought period in the Estuary, especially in March and 

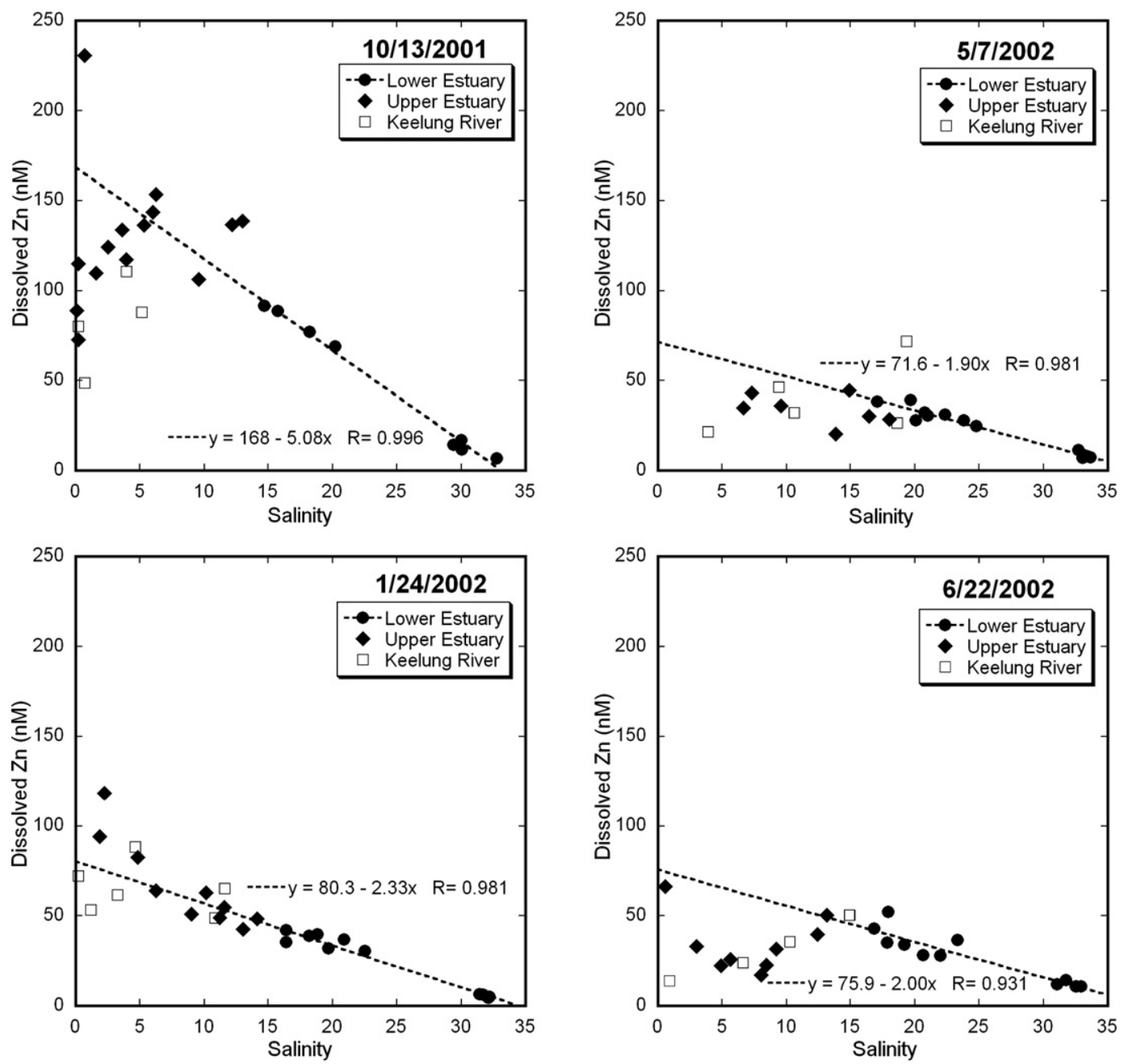

Fig. 9. Distribution of dissolved $\mathrm{Zn}$ along salinity gradients in the Danshuei River Estuary and modeled (implied mixing) regression of Zn and salinity in the lower estuary.

May 2002. Since the major removing mechanism for dissolved $\mathrm{Cd}$ and $\mathrm{Cu}$ in the Danshuei River Estuary is by precipitation of Cd and Cu sulfides (Zwolsman et al., 1997; Pohl and Hennings, 1999; Jiann et al., 2005), they may be more resistant to oxidation when estuarine water flows downstream and mixes with oxygen-saturated coastal water (Simpson et al., 2000). This may be the reason for much lower dissolved $\mathrm{Cd}$ and $\mathrm{Cu}$ fluxes out of the estuary. If during the dry, low river flow periods that the sub-oxic to anoxic condition in the estuary causing the formation of $\mathrm{Cd}$ and $\mathrm{Cu}$ sulfide minerals was the main removing mechanism, it is reflected in the observed distribution pattern of dissolved $\mathrm{Cd}$ and $\mathrm{Cu}$ in the Danshuei River Estuary. In the 4 months of drought condition since the oxygen-replenishing typhoon, dissolved $\mathrm{Cd}$ and sometimes $\mathrm{Cu}$ concentrations in the entire estuary were essentially lower than those in the coastal waters. Elevated $\mathrm{Cd}$ and $\mathrm{Cu}$ river endmember concentrations were probably brought to the estuary by the typhoon via increased

Table 2

Comparison of trace metal fluxes of the Danshuei River Estuary with other systems of the same magnitude of river discharge

\begin{tabular}{|c|c|c|c|c|c|c|c|c|}
\hline Estuary & $\begin{array}{l}\text { Study } \\
\text { period }\end{array}$ & $\begin{array}{l}\text { River discharge } \\
\left(\mathrm{m}^{3} / \mathrm{s}\right)\end{array}$ & $\begin{array}{l}\text { Cd flux } \\
\text { (mol/day) }\end{array}$ & $\begin{array}{l}\text { Cu flux } \\
\text { (mol/day) }\end{array}$ & $\begin{array}{l}\text { Ni flux } \\
\text { (mol/day) }\end{array}$ & $\begin{array}{l}\text { Pb flux } \\
\text { (mol/day) }\end{array}$ & $\begin{array}{l}\text { Zn flux } \\
\text { (mol/day) }\end{array}$ & Reference \\
\hline Scheldt & 1987-1988 & 186 & 252 & 8382 & & & 34,862 & Zwolsman et al. (1997) \\
\hline Clyde & 1989-1991 & 140 & 3.9 & 315 & 387 & 54 & 1818 & Muller et al. (1994) \\
\hline Seine & 1991 & 450 & $53-71$ & $630-945$ & $852-1022$ & $9.65-14.5$ & $3823-5352$ & Chiffoleau et al. (1994) \\
\hline Seine & 1994-1995 & 689 & 90 & 1596 & 1960 & 45 & 5320 & Chiffoleau et al. (1999) \\
\hline Gironde & 1997-1998 & $402-1530$ & $111-181$ & $1449-4614$ & & & $1605-2722$ & Michel et al. (2000) \\
\hline Danshuei & 2001-2001 & 120 & 0.66 & 255 & 3717 & 5.19 & 1317 & This study (average) \\
\hline
\end{tabular}


urban runoffs, combined with water conditions not favoring metal-sulfide formation. Instead, convex-shaped, addition behavior was observed after high river discharge for $\mathrm{Cd}$, possibly caused by desorption from suspended particulate matter (SPM) and the formation of chloride complexes (Cdhexachloro complexes) as ionic strength increases. Similar positive relationships between $\mathrm{Cd}$ and salinity during estuarine mixing have also been observed in low salinity regions of the Baltic after a flooding event (Pohl et al., 2002). As the drought continued from late 2001 until June 2002, the upper estuary was under sub-oxic to anoxic conditions throughout the 9-month period. Combining the effects of the absence of urban runoffs and stronger removal of $\mathrm{Cd}$ and $\mathrm{Cu}$ by sulfide species, dissolved $\mathrm{Cd}$ and $\mathrm{Cu}$ concentrations in the upper estuary progressively decreased from October 2001 to June 2002.

\subsubsection{Nickel}

Because Ni is less active and behaved near conservatively in the redox-sensitive Danshuei River Estuary, its flux simply reflects predominantly variation of its sources or variability of river endmember concentrations. Dissolved Ni flux out of the Danshuei River Estuary ranged between $1836 \mathrm{~mol} /$ day and $6586 \mathrm{~mol} /$ day. Only in January 2002 dissolved Ni showed significant internal removal (22\%, Table 1$)$, which has been attributed to $\mathrm{Ni}$ being less reactive toward reduced sulfur species in comparison with $\mathrm{Cd}, \mathrm{Cu}$, and $\mathrm{Pb}$ (Morel and Hering, 1993; Al-Farawati and van den Berg, 1999; Jiann et al., 2005). Although dissolved Ni showed internal inputs statistically on most occasions, it was affected by the dilution effect when low-Ni Keelung River water mixed with the Danshuei water. The mixed water had a lower Ni concentration compared to "pure" Danshuei water, and flowed upstream of the Danshuei River during the flood period. Except for the slightly removing feature found in January 2002, dissolved Ni can be regarded as behaving conservatively in the Danshuei River Estuary, indicating that there was very little internal input or removal of $\mathrm{Ni}$ in the estuary. On the other hand, fluxes of dissolved $\mathrm{Ni}$ out of the Danshuei River Estuary were high, mainly due to its high river endmember concentrations and low reactivity. In contrast to $\mathrm{Cd}$ and $\mathrm{Pb}, \mathrm{Ni}$ should be considered the element with concerns of high export loading out of the Danshuei River Estuary since dissolved Ni fluxes were constantly high (Table 1) and were higher than those in the Clyde and Seine Estuaries (Table 2).

\subsubsection{Lead}

Due to the great extent of removal, fluxes of dissolved $\mathrm{Pb}$ out of the Danshuei River Estuary were generally within a narrow range (2.47-6.79 $\mathrm{mol} / \mathrm{day}$, and $11.59 \mathrm{~mol} / \mathrm{day}$ in March, 2001), regardless of the river endmember concentrations. The removal is efficient (55-98\%, Table 1), in which dissolved $\mathrm{Pb}$ concentrations in the lower estuary and coastal waters were at times near background values for natural waters. Dissolved $\mathrm{Pb}$ concentrations fell into a narrow range in the lower estuary; therefore the $\mathrm{Pb}$-salinity relationships do not always possess great correlation coefficients, but should not affect our flux calculation. Since SPM is one of the major carriers on which $\mathrm{Pb}$ is adsorbed in estuaries, its concentration in the estuarine water plays an important role in determining partly the effectiveness of dissolved $\mathrm{Pb}$ removal. In the four sampling surveys with relatively small dissolved $\mathrm{Pb}$ removal rate $(<80 \%$, March and December of 2001, and January and May of 2002), SPM concentrations were generally lower than $20 \mathrm{mg} / \mathrm{L}$. When the percentages of $\mathrm{Pb}$ removing were greater (80-98\%) during other times, SPM concentrations in the upper estuary reached $40-183 \mathrm{mg} / \mathrm{L}$. The lower Danshuei River Estuary typically had SPM concentrations $<10 \mathrm{mg} / \mathrm{L}$, and the Danshuei coastal waters had 1-2 mg/L of SPM. Previous report has shown that under both high river flow time and dry season, dissolved $\mathrm{Pb}$ $(<0.45 \mu \mathrm{m}$ filter-passing) was present in mostly large colloidal forms (Jiann et al., 2005), unless in the lower estuary during high river flow time. Owing to its particle-reactive characteristics, $\mathrm{Pb}$ was removed in regions where 1 ) reduced sulfur species were present (river and upper estuary); 2) SPM concentration was higher, e.g., the upper estuary (Jiann et al., $2005)$; 3 ) the removal of Fe and Mn was the greatest, i.e., midto lower estuary where reduced Fe and Mn were oxidized to form oxides and oxyhydroxides that precipitate out of water column (Paucot and Wollast, 1997; Zwolsman et al., 1997; Zwolsman and van Eck, 1999), with the interface shifting according to redox state of the estuarine water. The removing mechanisms provided by elevated SPM in the upper estuary and flocculation of oxides and oxyhydroxides of Fe and $\mathrm{Mn}$ in mid- to lower estuary (Jiann et al., 2005) left nearly constant dissolved $\mathrm{Pb}$ concentration in the lower estuary, which in turn determined dissolved $\mathrm{Pb}$ flux out of the Danshuei River Estuary. Consequently, the flux of dissolved $\mathrm{Pb}$ out of the Danshuei River Estuary (5.19 mol/day) was much lower than those in the Seine (9.65-45 mol/day) and the Clyde Estuaries (54 mol/day) (Table 2).

\subsubsection{Zinc}

Dissolved Zn fluxes out of the Danshuei River Estuary were variable, ranging from $361 \mathrm{~mol} /$ day to $2656 \mathrm{~mol} / \mathrm{day}$. The fluxes are related to weather, or precipitation events, as the lower fluxes occurred during a prolonged period of low river discharge and extended estuarine sections with low DO (January and May 2002), while higher fluxes (October 2001 and June 2002) corresponded to higher river discharges following elevated precipitation days prior to our sampling dates (Fig. 2). This suggests that the effectiveness of $\mathrm{Zn}$ removal, and consequently the effective river endmember $\mathrm{Zn}$ concentrations resulted from variable redox conditions in the estuary, which itself is affected by river and wastewater discharges. Flux of dissolved $\mathrm{Zn}$ out of the Danshuei River Estuary (1317 mol/day) is the lowest among the estuarine systems compared (Table 2).

\section{Conclusions}

In the Danshuei River Estuary, a macro-tidal and partly anoxic estuary, physicochemical composition of water is strongly affected by climate and episodic events such as typhoons and torrential rains. Trace metal export loadings out of the estuary are dependent upon water composition, especially upon redox condition, which in turn is under the influence of estuarine hydrodynamics. In the low DO region of the estuary, formation of metal-sulfide minerals effectively removes dissolved trace elements such as $\mathrm{Cd}, \mathrm{Cu}, \mathrm{Pb}$, and $\mathrm{Zn}$ from water column. In mid-estuary, during the mixing of low 
DO, anoxic water, and oxygenated coastal water, a redox front forms and oxides and oxyhydroxides of Fe and Mn precipitate. This provides adsorbing carriers for trace metals, especially particle-reactive $\mathrm{Pb}$. This phenomenon is changed when an episodic high river discharge event occurs, such as a typhoon, which brings high volume of oxygenated water into the estuary and flushes the entire estuary. The strongest effect of high river discharge in an anoxic estuary may be that it changes redox condition of estuarine water, in addition to its dilution effect and elevated urban runoffs of trace metal sources. In the Danshuei River Estuary, the greatest extent of removal of trace metals, except for $\mathrm{Pb}$, was observed during very low river flow seasons, when low DO water stretched further down estuary. For $\mathrm{Pb}$, its removing mechanisms are more complicated, being affected by the presence of high SPM, by the formation of sulfide minerals, and by the formation and settling of Fe- and Mn-oxides and oxyhydroxides. Therefore, the behavior and fluxes of trace metals in the Danshuei River Estuary, being partly anoxic and having a relatively short flushing time, are driven by the alternating seasonal climate pattern and episodic weather events, which result in a fluctuating redox interface in the estuary. Therefore, restoration of dissolved oxygen in the Danshuei River Estuary will lead to much higher $\mathrm{Cd}, \mathrm{Cu}, \mathrm{Zn}$, and $\mathrm{Pb}$, but little difference of Ni fluxes into coastal area due to 1) less precipitation of metal-sulfide minerals; and 2) less Fe- and Mn-oxides and oxyhydroxides formation that removes trace metals. This is a situation similar to other estuaries with concerns of hypoxia such as the Scheldt Estuary (Zwolsman et al., 1997), and perhaps other estuaries near metropolitan areas.

\section{Acknowledgements}

The authors would like to thank the research assistants of the Chemical Lab of the National Center for Ocean Research (NCOR) for their efforts in field sampling and lab analyses. We thank two anonymous reviewers for their constructive comments and suggestions that helped improve the manuscript. This work was financially supported by the National Science Council of Taiwan (ROC) through research grants (NSC89-2119-M-002-016, NSC90-2119-M-002-016, and NSC91-2119-M-002-031) and NCOR at National Taiwan University.

\section{References}

Achterberg, E.P., Braungardt, C.B., Sandford, R.C., Worsfold, P.J., 2001. UV digestion of seawater samples prior to the determination of copper using flow injection with chemiluminescence detection. Analyt. Chim. Acta 440, 27-36.

Al-Farawati, R., van den Berg, C.M.G., 1999. Metal-sulfide complexation in seawater. Mar. Chem. 63, 331-352.

Chiffoleau, J.F., Cossa, D., Auger, D., Truquet, I., 1994. Trace metal distribution, partition and fluxes in the Seine estuary (France) in low discharge regime. Mar. Chem. 47, 145-158.
Chiffoleau, J.F., Auger, D., Chartier, E., 1999. Fluxes of selected trace metals from the Seine estuary to the eastern English Channel during the period August 1994 to July 1995. Cont. Shelf Res. 19, 2063-2082.

Honeyman, B.D., Santschi, P.H., 1988. Metals in aquatic systems. Env. Sci. Technol. 22 (8), 862-871.

Jiann, K.T., Presley, B.J., 2002. Preservation and determination of trace metal partitioning in river water by a two-column ion exchange method. Anal. Chem. 74 (18), 4716-4724.

Jiann, K.T., Wen, L.S., Santschi, P.H., 2005. Trace metal (Cd, Cu, Ni and Pb) partitioning, affinities and removal in the Danshuei River estuary, a macro-tidal, temporally anoxic estuary in Taiwan. Mar. Chem. 96 (3/4), 293-313.

Michel, P., Boutier, B., Chiffoleau, J.F., 2000. Net fluxes of dissolved arsenic, cadmium, copper, zinc, nitrogen and phosphorus from the Gironde Estuary (France): seasonal variations and trends. Estuar. Coast. Shelf Sci. 51, 451-462.

Morel, F.M.M., Hering, J.G., 1993. Principles and Applications of Aquatic Chemistry. John Wiley \& Sons, New York. 588 pp.

Muller, F.L.L., Tranter, M., Balls, P.W., 1994. Distribution and transport of chemical constituents in the Clyde Estuary. Estuar. Coast. Shelf Sci. 39, 105-126.

Officer, C.B., 1979. Discussion of the behavior of nonconservative dissolved constituents in estuaries. Estuar. Coast. Mar. Sci. 9, 91-94.

Ozturk, M., 1995. Trends of trace metal (Mn, Fe, Co, Ni, Cu, Zn, Cd and Pb) distributions at the oxic-anoxic interface and in sulfidic water of the Drammensfjord. Mar. Chem. 48, 329-342.

Paucot, H., Wollast, R., 1997. Transport and transformation of trace metals in the Scheldt estuary. Mar. Chem. 58, 229-244.

Pohl, C., Hennings, U., 1999. The effect of redox processes on the partitioning of $\mathrm{Cd}, \mathrm{Pb}, \mathrm{Cu}$, and $\mathrm{Mn}$ between dissolved and particulate phases in the Baltic Sea. Mar. Chem. 65, 41-53.

Pohl, C., Hennings, U., Siegel, H., Bachor, A., 2002. Trace metal impact into the Baltic Sea during the exceptional Oder flood in summer 1997. Mar. Chem. 79, 101-111.

Santschi, P.H., 1988. Factors controlling the biogeochemical cycles of trace elements in fresh and coastal marine waters as revealed by artificial radioisotopes. Limnol. Oceanogr. 33 (4,part 2), 848-866.

Santschi, P.H., Lenhart, J.J., Honeyman, B.D., 1997. Heterogeneous processes affecting trace contaminant distribution in estuaries: the role of natural organic matter. Mar. Chem. 58, 99-125.

Simpson, S.L., Apte, S.C., Batley, G.E., 2000. Effect of short-term resuspension events on the oxidation of cadmium, lead, and zinc sulfide phases in anoxic estuarine sediments. Env. Sci. Technol. 34, 4533-4537.

Wang, C.F., Hsu, M.H., Kuo, A.Y., 2004. Residence time of the Danshuei River estuary, Taiwan. Estuar. Coast. Shelf Sci. 60, 381-393.

Water Resource Agency, 2003. Water Information. Water Resources Agency, Minister of Economic Affairs (Taiwan). http://www.wra.gov.tw/WaterInfo/.

Wen, L.S., Stordal, M.C., Tang, D., Gill, G.A., Santschi, P.H., 1996. An ultraclean cross-flow ultrafiltration technique for the study of trace metal phase speciation in seawater. Mar. Chem. 55, 129-152.

Wen, L.S., Santschi, P., Gill, G., Paternostro, C., 1999. Estuarine trace metal distributions in Galveston Bay: importance of colloidal forms in the speciation of the dissolved phase. Mar. Chem. 63, 185-212.

Wen, L.S., Jiann, K.T., Liu, K.K., 2008. Seasonal variation and flux of dissolved nutrients in the Danshuei Estuary, Taiwan: a hypoxic subtropical mountain river. Estuar. Coast. Shelf Sci. 78, 694-704.

Windom, H.L., Byrd, J.T., Smith Jr., R.G., Huan, F., 1991. Inadequacy of NASQAN data for assessing metal trends in the nation's rivers. Env. Sci. Technol. 25 (6), 1137-1142.

Zwolsman, J.J.G., van Eck, G.T.M., 1999. Geochemistry of major elements and trace metals in suspended matter of the Scheldt estuary, southwest Netherlands. Mar. Chem. 66, 91-111.

Zwolsman, J.J.G., Van Eck, B.T.M., van der Weijden, C.H., 1997. Geochemistry of dissolved trace metals (cadmium, copper, zinc) in the Scheldt estuary, southwestern Netherlands: impact of seasonal variability. Geochim. Cosmochim. Acta 61 (8), 1635-1652. 